\title{
POSSIBLE PATHS FOR UNDERSTANDING HUMAN SCIENCES WITH MIKHAIL BAKHTIN
}

\section{PENSAR AS CIÊNCIAS HUMANAS COM MIKHAIL BAKHTIN: ALGUNS POSSÍVEIS PERCURSOS DE COMPREENSÃO}

\section{PENSANDO EN LAS CIENCIAS HUMANAS CON MIJAÍL BAJTÍN: ALGUNOS CAMINOS POSIBLES DE ENTENDIMIENTO}

Ivo Di Camargo Junior ${ }^{1}$

Fábio Marques de Souza ${ }^{2}$

Viviane Alves da Silva ${ }^{3}$

1. Portuguese Language Instructor at Ribeirão Preto's Education Bureau, in São Paulo/Brazil. santacrocce@ gmail.com

2. Professor at Art and Language Department at State University of Paraíba and Federal University of Campina Grande. fabiohispanista@gmail.com

3. Member of the research groups TECLIN (Technology and Language Studies) and Bakhtin Circle in Dialogue, registered at CNPq. vivianealvesuepb@gmail.com

\begin{abstract}
This article aims to offer an opportunity to think and question some of the possible paths to understanding Mikhail Bakhtin's contributions to the human sciences. Therefore, we will contextualize the ideas from Bakhtin Circle, connecting the semantic production of each one of its Russian members (such as Bakhtin, Medvedev, Volochinov, Kanaiev, Pumpianski and Judina) which provided a collaborative production that has been changing the way Western society thinks about human sciences throughout the last decades. These researchers perceptibly changed the studies on language philosophy, literary theory studies, and also offered a new perspective on discourse genres and basic concepts for linguistic and social studies, such as polyphony, alterity, dialogical relations, etc. These concepts function in relation to one another. We can perceive one element that has combined within itself this dialogue in a way it can provide the interaction between different knowledge areas, thinkers, researches and authors.
\end{abstract}

Keywords: Mikhail Bakhtin; Human Sciences; Bakhtin Circle; Language Philosophy; Literary Theory.
RESUMO: O objetivo desse artigo é proporcionar ao leitor a oportunidade de pensar e problematizar alguns possíveis percursos de compreensão das contribuições de Mikhail Bakhtin e o Círculo para as Ciências Humanas. Para isso, contextualizaremos as ideias do Círculo de Bakhtin, relacionando a produção e construção semântica de cada integrante do grupo russo: Bakhtin, Medvedev, Volochinov, Kanaiev, Pumpianski, Judina, entre outros, que nos proporcionaram uma produção coletiva que até hoje muda as bases do pensamento humanista desenvolvido no ocidente. Estes pesquisadores modificaram sensivelmente os estudos da filosofia da linguagem, estudos de teoria literária, ofereceram uma nova visão para os pensamentos de gêneros do discurso e ofereceram conceitos hoje basilares para os estudos linguísticos e humanos, como a polifonia, alteridade, relações dialógicas, etc. Estes conhecimentos funcionam em relação um com o outro. O que se percebe é um elemento que reuniu em si esse diálogo e que com seu nome promove essa interação entre as áreas do saber, com outros pensadores, pesquisas diversas de autores díspares.

Palavras-chave: Mikhail Bakhtin; Ciências Humanas; Círculo de Bakhtin; Filosofia da Linguagem; Teoria Literária.
RESUMEN: El propósito de este artículo es proporcionar al lector la oportunidad de pensar y discutir algunas formas posibles de comprender las contribuciones de Mijaíl Bajtín y el Círculo para las Humanidades. Para ello, contextualizamos las ideas del Círculo de Bajtín, relacionando la producción y construcción semántica de cada miembro del grupo ruso: Bajtín, Medvedev, Volochinov, Kanaiev, Pumpianski, Judina, entre otros, cuya producción colectiva hasta hoy cambia los fundamentos del pensamiento humanista desarrollado en Occidente. Estos investigadores han modificado significativamente los estudios de filosofía del lenguaje, los estudios de la teoría literaria, ofrecieron una nueva visión de los pensamientos de los géneros del discurso y ofrecieron conceptos que ahora son básicos para los estudios lingüísticos y humanos, como la polifonía, la alteridad, las relaciones dialógicas, etc. Este conocimiento funciona en relación el uno con el otro. Lo que se percibe es un elemento que reunió este diálogo y que con su nombre promueve esta interacción entre áreas de conocimiento, con otros pensadores, investigaciones diversas de autores dispares.

Palabras-clave: Mijaíl Bajtín; Ciencias Humanas; Círculo de Bakhtin; Filosofía del lenguaje; Teoría literaria.

Recebido em: 21/01/2020

Aprovado em: 21/04/2020

Todo o conteúdo deste periódico está licenciado com uma licença Creative Commons (CC BY-NC-ND 4.0 Internacional), exceto onde está indicado o contrário. 


\section{Introduction}

This article invites the reader to think and to go deep in the object of study. To go beyond what is already known. The Bakhtinian thought calls itself a for an immersion experience. It instigates the reader to contextualize the ideas of the Circle and to connect the semantic construction of each member of the Russian group, which is the main objective of this paper. Bakhtin, Medvedev, Volochinov, Kanaiev, Pumpianski and Judina, among others, made a collaborative production that, to this day, changes the basis of humanist studies developed in the West.

These researchers have sensitively changed the studies in literary theory, by offering a new perspective to discourse genres and basic concepts to linguistic and human studies such as polyphony, alterity, dialogical relations, etc. These concepts function in relation to one another. Although there is one element that has combined within itself the dialogue in a way it can provide the interaction between different knowledge areas, thinkers, researches and authors. This element is Mikhail Bakhtin. He brings within himself the union of different voices, a characteristic that makes difficult to consider the Circle as provider of "structuralist" (monophonic) thoughts. To frame his ideas is the same as killing them. It would terminate the dialogism that highlights the thoughts of the Circle.

In other words, to promote the structuralist concepts into the Circle would be paradoxical. It is the same as to bury the poetic works of Fernando Pessoa by joining together each one of his heteronymous. This example is also Bakhtinian. The complexity that occurs within the Circle is its main feature. We do not intend to reunite all concepts in one, because having two voices of dialogue is the basis of every Bakhtinian thought. The Self and the Other, just like the social environment.

As we move on to debate about these themes and thoughts, we can search for a new way to see the human through dialogism and alterity. We can listen to the polyphony of existing voices inside each person. In Brazil, since the beginning of 1980, with the studies of the Ukrainian, Boris Schnaiderman, we have seen researches that propose a new dialogue with recent studies which resulted in an interaction among themselves and other theories and researchers. It is a relation that acts from inside out, in centrifugal force and from outside to inside, as centripetal force. That changes the way we perceive the world, with new time, space and subject relations. All of this comes to transform and reshape a way of thinking that tried to be structured by the western academy until 1970. Bakhtin and his Circle, with studies carried out from 1910 to 1975 change the perception of life in order to suggest a new humanism, with reflex and refraction, by showing the Self and the Other that exist within each person.

\section{A further study}

To develop a paper that portraits Bakhtin as a relevant and distinguished philosopher can leads us to process dialogical concepts on language that affect not only theoretical questions but also human analysis issues. Essentially, we will present a broader view through the dialogical aspect, mainly because the ideas in the Circle move in so many directions and fields of study that, to classify them could result in a diminishment of great ideas into a few structured concepts that certainly would not represent their magnitude.

The dialogue is the basis of all language philosophy in Bakhtin's Circle. Even though some critics argue that there is no method for these studies, here we consider that the dialogism itself is a method as 
valid as the Cartesian, used in exact sciences. Therefore, the dialogue is crucial within the interaction between ideas and members of the Russian group of study. They considered language as a living organism, constantly evolving, and if we observe the research produced by the Circle, we will reach the conclusion that language is not simply an analysis tool, but also a relation between what is observed and the observer. Bakhtin and his colleagues developed a lot of studies that built bridges and broke paradigms, by offering a view towards the Other, as a way of better understanding each other.

Bakhtin was considered a language philosopher, a linguist, a theorist of literary studies and religious discourse, a historian of cultural studies, who interacted with Freud and Russian formalists of his time through his books. In his life, for many decades, he was unaffected by the status quo, having endured exile in Kazakhstan, a severe disease that ultimately resulted in a leg amputation and also lack of basic resources, all of them consequences of a decaying Russian State. Maybe that is the reason why academics such as Schnaiderman considered him as one of the most relevant and inexplicable personalities in the last century.

The Bakhtinian Circle was caught in the middle of a bustling time in Russian history. From the end of 1910s to the beginning of 1930s, the country had been through a revolution that have changed the courses of the twentieth century. There is no possibility of stating the existence of the Circle without the productive friendship between Bakhtin, Voloshinov and Medvedev. Together and aligned with other fellows they have formed a resistance against Stalin's violations, and with independent or co-operative papers they have developed a new perspective for the human sciences during the twentieth century. Therefore, to understand the concepts of ideology and ideologic sign in a fundamental work such as "Marxism and the philosophy of language", can show us the significance of this thought. It represents how the social and ideological phenomenon reflects on human societies.

Understanding the concept of ideologic sign can connect us to the essence of Bakhtinian thought, since it demonstrates the material characteristic of every ideological event. Bakhtin and Volochinov stated that an ideology can be demonstrated through a semiotic material, because everything that has been expressed or can be expressed will carry an ideologic value. A word, text, discourse, everything has its own criteria in an interaction. Intonation itself can be an ideologic variety, since different humans can use the same language to say different things. Thus, the ideologic sign will find expressions of value or ideological character within itself. It can portray what has been lived, individually or collectively, as a way of assumption or opposition. It can be monological or dialogical, polyphonic. Bakhtin's Circle has offered their input to all of these concepts through a contribution to society's values and its present ideology and community.

The works produced by the Circle were presented to the western scenario in 1960, when Julia Kristeva brought Bakhtin's studies on literature from Bulgaria. The strength of these studies had been used in many researches until Jacqueline Authier-Revuz deepen her studies and developed, in 1980, the concept of "Enunciative heterogeneity". The French author proposed an extension of the studies offered by the Circle related the presence and evidence of the Other in discourse. This can lead us to think about the studies done by Foucault and Pêcheux as dialogical, even though Pêcheux has refused the dialogue at first. It was only at the end of his productions, in 1980, that Pêcheux admitted ideas from the Circle through the dialogical perspective, however, in few and rare moments of his work on discourse, structure or event. Therefore, we are able to develop this thought and look into the French Discourse Analysis to know if there is a connection between the Circle and Discourse Analysis or even if one exists because of 
the other. If we consider history, it is impossible to consider that Bakhtin is related to French Discourse Analysis. While Bakhin and the Circle developed their studies from the beginning of the 20th century, the French studies would only begin in 1960 and reach their peak in 1980. That is why the strength of the Circle is the capacity of dialogue with another theory even if there are differences and contradictions between them, which is part of the Circle's thinking that there must be always a dialogue, different voices and anything else to promote inequality.

In Brazil, the book "Marxism and Philosophy of Language", originally published in 1929 by Volochinov, was translated directly from French in 1981, but it was not until the end of this decade and the early 1990s that Bakhtin, still without the Circle, began to be discussed as a strong theorist and started to get accepted by the national academy. In pedagogy, a field which already accepted the contributions of Bakhtin's countryman, the psychologist Vigotski accepts thoughts of the Circle theorist. The social sciences are able to perceive in the aforementioned work a Marxism that witnessed the massification of Soviet censorship, both in life and in work and this also remains in history.

In 1929, Bakhtin published his book entitled "Problems of Dostoyevsky's Poetics", which would be relaunched only 34 years later. This work was named after the Russian master and deals for the first time with the theme of the polyphonic novel, placing Dostoyevsky as the creator of this type of novel, where several contradictory ideological voices would exist in the narrator and characters. Regarding the production of literary theory, Bakhtin published years later his doctoral thesis, which was written in 1940 and presented in 1951 that got approved, after numerous discussions by the examining board who denied him the title of doctor. The book "Rabelais and His Work: carnival and grotesque " brought the elaborate concept of carnavalization by placing laughter as a power that demolished the plastered social conventions and revealed in language the conflicts existing in society. A work that came out in the year of Bakhtin's death, "Questions of literature and aesthetics" brought together texts from the 1930s that discussed questions of authorship, style and theorization on the concept of the hero. These works placed Bakhtin in the same level of respected authors in literary theory and legitimized him within this category.

Thus, over time, more and more "Bakhtins" have emerged and developed a sophisticated personality in human studies, mainly in literature. However, in the meantime, a suspicion about the authorship of the texts published by Bakhtin began to arise. At the same time, other unpublished texts appeared in the 1930s and 40s. These papers were linked to a vision attached to the philosophy of language and literature, consisting of texts considered different such as the text "Contemporary Vitalism", about the physiological form of the brain (signed by I. I. Kanaiev and published in 1926) and the book "The Freudism" signed by Volochinov, published in 1927. This is one of the debates around the Circle that resulted in dialogues based on linguistic theory.

With all the offer of studies and papers that arose in the intellectual environment over the years, it was natural to consider that interpretation and analysis mistakes occurred, mostly because Bakhtin's work had not been analyzed as it should. If we only consider the appearance of his works in the West, coming from literary, philosophical and language studies, we can understand the reason why his works were so successful in several areas of knowledge. In the field of language, Saussure and Chomsky had a larger influence. While Bakhtin, with the dialogues his theory offered, promoted a more fresh and humanized discussion in the area. In literature, structuralism, in a shared dominance with formalism, obtained a greater freedom of voices, a new way of perceiving what characters and authors could offer and receive from the reader, with a division of the novels into monological and polyphonic. Bakhtin and the Circle 
made Literature to be perceived with a greater relationship with its inscription within social and history, allowing us to appreciate even more of the ideological and human context in which it was inserted.

In this intellectual context, the studies that expanded the work of the Circle arise. Papers by Kristeva, Authier-Revuz, the biography produced by Clark and Holquist, brought insights into the work of Bakhtin and his circle of authors that changed human sciences forever. The Circle later would be considered a necessary and almost obligatory study for those who wish to deepen their gaze into a study that offers a vision focused on the other and how it changes society.

Bakhtin and the Circle studies guide us towards two positions that are the relationship between the interactionists, who are interlocutors that will interact with each other and other subjects in society. For Bakhtin, the studies produced by an interactionist perspective can promote a greater humanization and a more comprehensive sociologization; for him, a speech is never individual because it will be developed between two or more interlocutors. It cannot be individual, since an interaction requires two or more subjects or discourses. Considering Textual Linguistics, a text requires previous knowledge of the other texts (shared knowledge) that were part of the momentaneous interaction between the participants, in order to be correctly received.

There are several academic and scientific events, whether in Brazil or other countries, that discuss Bakhtin's teachings and intellectual developments and it only proves the validity of his theory. Many research groups around the world show interest in his studies and continuously seek to improve his works. Thus, publishing this article that synthesizes the human value of Bakhtinian concepts, provides the possibility of showing the reader a growing scenario of interest in social and ideological issues that prioritize dialogue as a human issue. This makes us understand Bakhtin's value as a language and literature scientist and philosopher. A unique and dialogically heterogeneous character.

\section{Intellectual Basis}

This article aimed to highlight the importance of broadcasting studies about Bakhtin Circle and to demonstrate their importance as humanities thinkers. When we look at the number of areas of human intellect that consider Bakhtin and his circle a reference for research, we are able to realize the dialogic language relations that make Bakhtin a conceptual author who promotes intellectual debate among areas and researchers from different segments.

The production of this text can be justified by the concern of legitimizing the Russian thinker and his associates as essential to human sciences. It is believed that the dialogue held in this discussion, covering many aspects of human knowledge, will guarantee a new way of perceiving Bakhtin and his circle as authors that developed ideas mainly in a transdisciplinary approach. Therefore, it is important to promote the reflection and refraction of the group's ideas, so that they do not fit into only one area of knowledge. It is necessary for the texts discussed, to use Bakhtinian concepts in order to offer a broader possibility for these studies in their philosophies and intellectual productions.

Another relevant point of view can be found in the way that Bakhtinian concepts are mobile and move through different areas. This will highlight the dialogical conception of language and that is why an analysis of how the development and clash between Bakhtinian structuralism and dialogical relations occurred is still necessary in analyses that seek an evolution of humanism in Western studies. 
For the historical matter, we can observe how special it is to consider the Bakhtinian and the circle production in Russia, in the western world and here in Brazil. It is possible to sense the intention of building a past, valuing studies done in the present and projecting an adequate future for more farreaching studies. If we analyze the Circle since the dissemination of the studies, we perceive a continuous depth that stablishes it as a relevant area even with 'the lack of a method', which critics that are not familiar with the theory so often despise. They do not understand that all Bakhtinian and Circle writings have a method that escapes only one work and can only be found in a broad and contextualized reading of the writings.

It should also be noted that areas that were in competition with Bakhtin's Circle studies until decades ago, such as the French Speech Analysis, nowadays dialogue with Bakhtinian studies in strong academic research. Their projects bring benefits to society, with a clearer and more precise understanding and reveal of nuances that were previously forgotten or erased from the collective memory. In the literary field, themes such as poetics, questions of authorship, style, the recognition of carnavalization in texts, concepts of chronotopy and exotopia, and many others are finally considered indispensable for a serious and competent literary analysis in literature theory today.

In the pedagogical field, researches with concepts of the Circle are productive because of the incorporation of Bakhtin's concepts within the National Curricular Parameters, especially with the matter of the discourse genre. It brought a new look into the educational practice, which only denotes an importance for the area, because it now integrates public selective processes for future teachers throughout the country.

The philosophical aspect of discourse and humanism should be highlighted, in which Bakhtin and Volochinov stated that the word was "the purest and most sensitive mode of social relationship" (2006, p. 36). If we analyze this issue, we can perceive a discursive perception of life, which is the basis of Bakhtin's vision of the Subject and his circle.

In conclusion, the thought process that this article intended to convey is: to see Bakhtin and his Circle as producers of a broad and multidisciplinary knowledge that should be analyzed, so as not to exhaust its potential but to disseminate a polyphonic and dialogic knowledge that makes the Russians of Bakhtin's Circle special authors: who are specialized in promoting dialogues, debates, alterity and the promotion of difference as a condition for human evolution.

\section{References}

BAKHTIN, M./VOLOCHINOV. Marxismo e Filosofia da Linguagem. São Paulo: Hucitec, 2006.

. Discurso na vida e discurso na arte. (trad. Carlos Alberto Faraco), 1926.

BAKHTIN, M. Estética da Criação Verbal. São Paulo: Martins Fontes, 1992.

. Problemas da poética de Dostoiévski. Rio de Janeiro: Forense-Universitária, 1981.

. A cultura popular na Idade Média e no Renascimento: o contexto de François Rabelais. São

Paulo: Hucitec, 1987.

Questões de literatura e estética: a teoria do romance. São Paulo: Hucitec/ USP, 1988.

O Freudismo. São Paulo: Perspectiva, 2004

BEZERRA, P. Prefácio à segunda edição brasileira. In BAKHTIN, M. Problemas da poética de Dostoievski. Rio de Janeiro: Forense Universitária, 1981. 
BRAIT, B. (org.). Bakhtin - conceitos-chave. São Paulo: Contexto, 2005.

Bakhtin - outros conceitos-chave. São Paulo: Contexto, 2006.

BRAIT, B. "Análise e teoria do discurso". In BRAIT, B. (org.). Bakhtin - outros conceitos-chave. São Paulo: Contexto, 2006.

CLARK, K.; HOLQUIST, M. Mikhail Bakhtin. São Paulo: Perspectiva, 1998.

DI CAMARGO, I. Jr. Mikhail Bakhtin na linguagem cinematográfica. São Paulo: Mentes Abertas, 2020 [no prelo].

. A Memória de Futuro em tela: diálogos entre o Cinema e Mikhail Bakhtin. São Paulo: Mentes Abertas, 2020.

MIOTELLO, V. Bakhtin em trabalhos de estudo da língua: levantando o problema do pertencimento. Estudos Linguísticos, Campinas, v. XXXV, p. 176-180, 2006.

Discutindo a questão do dialogismo com Bakhtin. Versão Beta, São Carlos, n. 25, p. 31-50, 2003.

$02-10$

Compreendendo alguns conceitos bakhtinianos. Versão Beta, São Carlos/SP, n. 10, 2002, p.

Estudo da língua em Bakhtin - objeto e metodologia. In: Sandra Regina Buttros Gattolin; Mônica Baltazar Diniz Signori; Valdemir Miotello. (Org.). Década - Dez anos entre o aprender e o ensinar linguagens. São Carlos/SP: Pedro \& João Editores, 2007, p. 275-286.

As palavras engravidam e grávidas dão à luz um mundo novo. In: Grupo de Estudos dos Gêneros do Discurso - GEGE. (Org.). O Espelho de Bakhtin. 1ª ed. São Carlos/SP: Pedro \& João Editores, 2007, p. 185-206.

. A Memória do Passado em jogo com a Memória do Futuro constitui sentidos agora. Daí que os Projetos de Dizer dos sujeitos têm importância. In: André Luiz Covre, Fabrício de Oliveira, Valdemir Miotello e outros. (Org.). Veredas Bakhtinianas - de objetos a sujeitos. São Carlos: Pedro \& João Editores, 2006, p. 277-286.

. Ideologia. In: Beth Brait. (Org.). Bakhtin - Conceitos-chave. São Paulo: Editora Contexto, 2005, p. 167-177.

PONZIO, A. La revolución bajtiniana. Madri: Catedra, 1999.

A Revolução Bakhtiniana. São Paulo; Editora Contexto, 2008. 